\title{
Yield and Fruit Quality Traits of Carambola Cultivars Grown at Three Locations in Puerto Rico
}

\author{
Ricardo Goenaga ${ }^{1}$
}

ADDITIONAL INDEX wORDs. fruit length, fruit diameter, soluble solids concentration, Averrboa carambola

SUMMARY. There is a scarcity of information on how carambola (Averrhoa carambola) cultivars perform in various agroenvironments. Nine carambola cultivars-Arkin, B-10, B-16, B-17, Kajang, Kari, Lara, Sri Kembangan, and Thai Knight-grown on an Oxisol, an Ultisol, and a Mollisol were evaluated for 4 years under intensive management at Isabela, Corozal, and Juana Díaz, PR, respectively. There were no significant differences in number and weight of marketable fruit per hectare area among locations averaging 258,761 fruit/ha and $30,978 \mathrm{~kg} \cdot \mathrm{ha}^{-1}$, respectively. There were no significant differences of marketable fruit weight per hectare among highest yielding cultivars B-17, Thai Knight, and Sri Kembangan between locations. The average marketable fruit weight for these highest-yielding cultivars was $36,060 \mathrm{~kg} \cdot \mathrm{ha}^{-1}$. 'Arkin' and 'B-16' were the lowest yielding cultivars, averaging $23,490 \mathrm{~kg} \cdot \mathrm{ha}^{-1}$ of marketable fruit. 'Kari' produced significantly longer fruit at all locations, whereas 'B-16' produced the shortest fruit. Significantly higher soluble solids concentration values were obtained from fruit of ' $\mathrm{B}-17$ ' at all locations, whereas lower values were obtained from those of 'Arkin'. Overall, cultivars were highly adaptable to the diverse agroenvironments in which they were planted. The fact that ' $B-17$ ' had high production of marketable fruit, high marketable yield, and high soluble solids concentration at all locations makes this cultivar suitable for planting in diverse agroenvironments.

$\mathrm{C}$ arambola or star fruit is native to Indonesia but has been cultivated throughout southeast Asia and Malaysia for many centuries (Shaw and Wilson, 1998). The tree adapts to a wide range of conditions in tropical and subtropical climates; however, better fruit quality and higher yields are produced under tropical conditions and annual rainfall of $\approx 1800 \mathrm{~mm}$ (Galan-Sauco et al., 1993). Carambola trees adapt well to almost any soil type, from sand to heavy clay loam to rocky calcareous soils (Nakasone and Paull, 1998). On alkaline soils, however, deficiencies of $\mathrm{Fe}, \mathrm{Mn}$, and $\mathrm{Z}$ may occur (Marler et al., 1994).

United States Department of Agriculture, Agricultural Research Service, Tropical Agriculture Research Station, 2200 P.A. Campos Avenue, Suite 201, Mayaguez, PR 00680-5470

I thank Edmundo Rivera, Nicolás Díaz, Angel Marrero, Tomás Soto, and Tomás Miranda for their excellent field assistance, and Victor Chew for assistance in statistical analyses.

Mention of trade names or commercial products in this publication is solely for the purpose of providing specific information and does not imply recommendation or endorsement by the U.S. Department of Agriculture.

${ }^{1}$ E-mail: Ricardo.Goenaga@ars.usda.gov
There is little information available on total production area of carambola worldwide. Taiwan, Malaysia, and Brazil are the largest producers of carambola, with estimated production ranging from 3000 to 40,000 $\mathrm{Mg}$. Florida is the largest production area in the United States, with 260 ha under cultivation and a crop worth $\$ 17.4$ million in 1996. In 2000, however, averages had declined to $\approx 100$ ha (Mossler and Nesheim, 2002).

Commonly used cultivars for commercial production include 'Arkin', 'Kary', 'B-10' (Florida), 'Cheng Tsey' (Taiwan), 'B-17'
(Malaysia), 'Fwang Tung' (Thailand), and 'Icambola' (Colombia) (Campbell, 1997; Galan-Sauco et al., 1993; Marler et al., 1994; Nakasone and Paull, 1998). However, replicated field trials to evaluate these and other carambola cultivars have been very limited. The purpose of this study was to evaluate yield performance and fruit quality traits of nine carambola cultivars grown in various agroenvironments.

\section{Materials and methods}

The study was conducted in Puerto Rico at the U.S. Department of Agriculture, Agricultural Research Service Research Farm in Isabela (Coto clay: clayey, kaolinitic isohyperthermic Typic Hapludox), at the Corozal Agricultural Expt. Sta. of the University of Puerto Rico (UPR) (Corozal clay: clayey, mixed, isohyperthermic Aquic Haplohumults), and at the UPR-Juana Diaz Agricultural Expt. Substation (San Anton: fine-loamy, mixed isohyperthermic Cumulic Haplustoll). Soil and climatic characteristics are described in Tables 1 and 2 .

Six-month-old trees of cultivars Arkin, B-10, B-16, B17, Kajang, Kari, Lara, Sri Kembangan, and Thai Knight grafted onto 'Golden Star' rootstocks were transplanted to the field 9 Feb. 1999 (Isabela), 17 Mar. 1999 (Corozal), and 3 June 1999 (Juana Diaz), and were arranged in a randomized complete-block design with six replications at each location. Planting holes about $1.5 \mathrm{ft}$ deep were dug with an auger connected by a drive shaft to the power take-off unit of a tractor. At transplanting, each plant received $11 \mathrm{~g}$ granular $\mathrm{P}$ provided as triple superphosphate. Within a replication, plots for each cultivar contained two trees spaced

\begin{tabular}{llll}
\hline $\begin{array}{l}\text { Units } \\
\text { To convert U.S. to SI, } \\
\text { multiply by }\end{array}$ & U.S. unit & SI unit & $\begin{array}{l}\text { To convert SI to U.S., } \\
\text { multiply by }\end{array}$ \\
\hline 0.4047 & acre $(\mathrm{s})$ & $\mathrm{ha}$ & 2.4711 \\
0.3048 & $\mathrm{ft}$ & $\mathrm{m}$ & 3.2808 \\
3.7854 & gal & $\mathrm{L}$ & 0.2642 \\
2.5400 & inch(es) & $\mathrm{cm}$ & 0.3937 \\
25.4000 & inch(es) & $\mathrm{mm}$ & 0.0394 \\
1.1209 & lb/acre & $\mathrm{kg} \cdot \mathrm{ha}^{-1}$ & 0.8922 \\
28.3495 & $\mathrm{oz}$ & $\mathrm{g}$ & 0.0353 \\
1 & $\mathrm{ppm}$ & $\mathrm{mg} \cdot \mathrm{kg}^{-1}$ & 1 \\
6.8948 & $\mathrm{psi}$ & $\mathrm{kPa}$ & 0.1450 \\
0.9072 & ton $(\mathrm{s})$ & $\mathrm{Mg}$ & 1.1023 \\
$\left({ }^{\circ} \mathrm{F}-32\right) \div 1.8$ & ${ }^{\circ} \mathrm{F}$ & ${ }^{\circ} \mathrm{C}$ & $\left(1.8 \times{ }^{\circ} \mathrm{C}\right)+32$
\end{tabular}


Table 1. Average preplant soil characteristics at three carambola test sites in Puerto Rico measured to a depth of 12 inches.

\begin{tabular}{lrrr}
\hline & \multicolumn{3}{c}{ Location } \\
\cline { 2 - 4 } Soil characteristics & $\begin{array}{c}\text { Corozal } \\
\text { (Ultisol) }\end{array}$ & $\begin{array}{c}\text { Juana Díaz } \\
\text { (Mollisol) }\end{array}$ & $\begin{array}{r}\text { Isabela } \\
\text { (Oxisol) }\end{array}$ \\
\hline $\mathrm{pH}$ in water & 4.75 & 8.28 & 6.62 \\
$\mathrm{pH}$ in calcium chloride & 4.11 & 7.85 & 6.06 \\
Ammonium nitrogen $\left(\mathrm{mg} \cdot \mathrm{kg}^{-1}\right)^{\mathrm{z}}$ & 23.01 & 14.00 & 11.05 \\
Nitrate nitrogen $\left(\mathrm{mg} \cdot \mathrm{kg}^{-1}\right)$ & 9.17 & 14.00 & 6.60 \\
Organic C $(\%)$ & 1.19 & 0.41 & 1.20 \\
$\mathrm{P}\left(\mathrm{mg} \cdot \mathrm{kg}^{-1}\right)$ & 5.88 & 104.00 & 15.79 \\
$\mathrm{~K}\left(\mathrm{mg} \cdot \mathrm{kg}^{-1}\right)$ & 53.67 & 650.00 & 469.80 \\
$\mathrm{Ca}\left(\mathrm{mg} \cdot \mathrm{kg}^{-1}\right)$ & 1551.00 & 3158.00 & 1654.00 \\
$\mathrm{Mg}\left(\mathrm{mg} \cdot \mathrm{kg}^{-1}\right)$ & 62.00 & 337.00 & 67.80 \\
\hline
\end{tabular}

${ }^{\mathrm{z}} \mathrm{lmg} \cdot \mathrm{kg}^{-1}=1 \mathrm{ppm}$.

Table 2. Historical weather data at three carambola test sites in Puerto Rico $(\mathbf{n}=\mathbf{5 8}$ years $)$.

\begin{tabular}{lccc}
\hline & \multicolumn{3}{c}{ Location (soil) } \\
\cline { 2 - 4 } Site characteristic & $\begin{array}{c}\text { Corozal } \\
\text { (Ultisol) }\end{array}$ & $\begin{array}{c}\text { Juana Díaz } \\
\text { (Mollisol) }\end{array}$ & $\begin{array}{c}\text { Isabela } \\
\text { (Oxisol) }\end{array}$ \\
\hline Rainfall $(\mathrm{mm})^{\mathrm{z}}$ & 1863 & 917 & 1649 \\
Evaporation $(\mathrm{mm})$ & 1391 & 2149 & 1672 \\
Temperature max. $\left({ }^{\circ} \mathrm{C}\right)^{\mathrm{z}}$ & 29.7 & 31.2 & 29.8 \\
Temperature min. $\left({ }^{\circ} \mathrm{C}\right)$ & 19.8 & 20.8 & 19.9 \\
Temperature mean $\left({ }^{\circ} \mathrm{C}\right)$ & 24.7 & 26.0 & 24.9 \\
Elevation $(\mathrm{m})^{\mathrm{z}}$ & 195 & 21 & 126 \\
\hline
\end{tabular}

${ }^{\mathrm{z}} 1 \mathrm{~mm}=0.0394$ inch; $\left(1.8 \times{ }^{\circ} \mathrm{C}\right)+32={ }^{\circ} \mathrm{F} ; 1 \mathrm{~m}=3.2808 \mathrm{ft}$.

$12 \mathrm{ft}$ apart and $18 \mathrm{ft}$ between adjacent rows in a triangular array. The experiments were surrounded by two guard rows of 'Golden Star' seedlings. Irrigation based on tensiometer readings was provided with spinner jets (model DXMAG368X; Maxijet, Dundee, FL) spaced $12 \mathrm{ft}$ apart and providing $13.5 \mathrm{gal} / \mathrm{h}$ at $20 \mathrm{psi}$. Fertilization was provided every 3 months using a $15 \mathrm{~N}-2.2 \mathrm{P}-16.3 \mathrm{~K}-1.8 \mathrm{Mg}$ commercial mixture at a rate of $498 \mathrm{~kg} \cdot \mathrm{ha}^{-1}$. Herbicide for weed control was applied only in strips within the planting row.

Harvests were initiated in Aug. 2001 at all locations. At each harvest, number and weight of marketable and nonmarketable fruit were recorded and weighed. Deformed fruit and those measuring less than $10 \mathrm{~cm}$ in length and $5.5 \mathrm{~cm}$ in diameter were considered nonmarketable. Representative fruit totaling $10 \%$ of those harvested were used to determine fruit length and diameter. Soluble solids readings were also recorded with a temperaturecompensated Packet PAL-1 digital refractometer (ATAGO Co., Ltd., Tokyo, Japan) when the fruit ripened, about 2 to $3 \mathrm{~d}$ after harvest. The experiment was ended in Aug. 2005.
Analysis of variance was carried out using the GLM procedure of SAS (release 9.0 for Windows; SAS Institute, Cary, NC). After significant F test at $P \leq 0.05$, means separation was performed with LSD.

\section{Results and discussion}

Location, cultivars, and year showed highly significant effects $(P \leq$ 0.01 ) on most fruit parameters measured in the study. Exceptions were number of marketable fruit and marketable weight per hectare, which did not show a significant location effect. The cultivar $\times$ location interaction was significant for total number of fruit, number of nonmarketable fruit, nonmarketable fruit yield, and fruit soluble solids but not for number of marketable fruit, marketable fruit yield, total yield, fruit length, and fruit diameter (Table 3). Except for fruit length and diameter, the year $x$ cultivar interaction was also highly significant for most fruit variables. Overall, cultivars exhibited an increase in the number of marketable fruit and weight during the first 3 years of production and then leveled off on the fourth year (Table 4). This response was expected as trees increased in age. However, the magnitude of this response varied among cultivars as expected by the significant year $\times$ cultivar interaction (Table 3 ). 'Arkin', 'B-10', 'B-16', 'Kajang', 'Lara', and 'Thai Knight' had an increase in the number of marketable fruit and marketable yield during the first 3 years and then declined or leveled off. In contrast, these variables increased in 'B-17,' 'Kari,' and 'Sri Kembangan' throughout the experimental period (Table 4).

'Sri Kembangan', 'Thai Knight', and ' $\mathrm{B}-17$ ' had the three highest 4year mean for number and yield of marketable fruit (Table 4). 'Sri Kembangan' had the highest number of marketable fruit and marketable yield in 2 of the 4 years the experiment lasted, and the highest 4-year mean for these variables. ' $\mathrm{B}-16$ ' had the lowest 4-year mean for number of marketable fruit and marketable yield.

Total number of fruit was significantly different among locations, with more fruit produced in Corozal $(793,735$ fruit/ha) and less at Isabela (479,759 fruit/ha; Table 3 ). A possible explanation on why more fruit were produced at Corozal than at other locations may be that this site is less windy than Isabela and Juana Diaz. Windy conditions have been reported to be detrimental to carambola fruit production (Crane, 2005; Galan-Sauco et al., 1993), but the effects of wind on physiological processes of carambola are still unknown (Marler et al., 1994). The number of marketable fruit was not significantly different among locations averaging 258,761 fruit/ha. At Corozal, the number of marketable fruit constituted only $31 \%$ of the total fruit harvested whereas at Juana Diaz and Isabela it was $41 \%$ and $55 \%$ respectively (Table 3 ). Chemical fruit or flower thinning to reduce crop load and increase fruit size is not a standard cultural practice in carambola production. The potential of fruit thinning in carambola is being studied by the author to find out if this practice is a potentially profitable one for this crop. Studies in other crops have shown that fruit thinning often reduces returns to the growers (Davis et al., 2004). The average marketable fruit weight was also similar among locations averaging $30,978 \mathrm{~kg} \cdot \mathrm{ha}^{-1}$. Average fruit length and diameter were significantly greater at Isabela 


\section{VARIETY TRIALS}

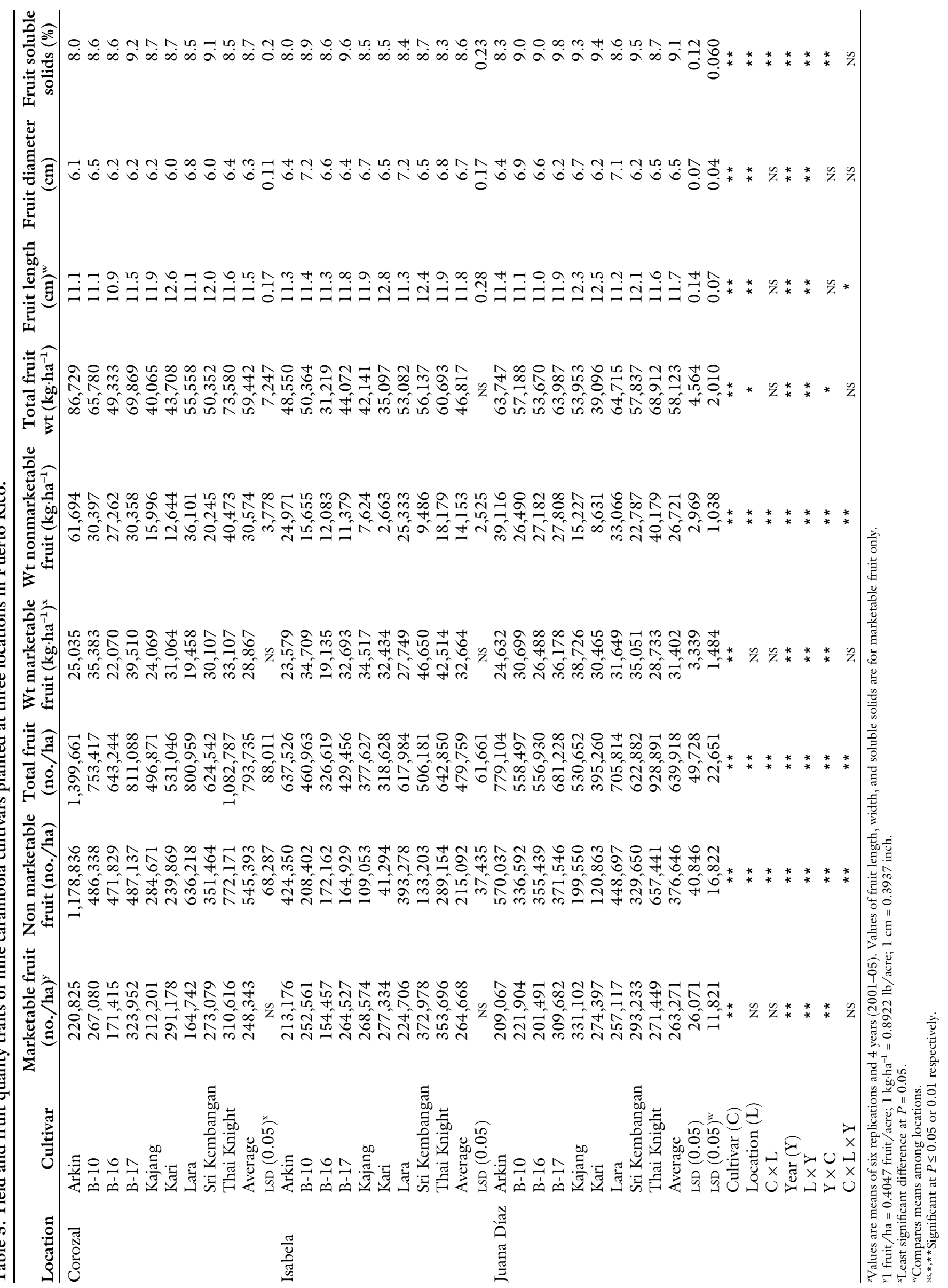


Table 4. Number and yield of marketable fruit of nine cultivars of carambola grown in Puerto Rico.

\begin{tabular}{|c|c|c|c|c|c|c|c|c|c|c|}
\hline \multirow[b]{2}{*}{ Cultivar } & \multicolumn{5}{|c|}{ Marketable fruit (no./ha) ${ }^{\mathrm{z}}$} & \multicolumn{5}{|c|}{ Marketable wt $\left(\mathrm{kg} \cdot \mathrm{ha}^{-1}\right)^{\mathrm{z}}$} \\
\hline & 4-yr & 2002 & 2003 & 2004 & 2005 & $4-y r$ & 2002 & 2003 & 2004 & 2005 \\
\hline Arkin & 214,355 & 141,197 & 220,776 & 260,116 & 235,333 & 24,414 & 17,284 & 24,499 & 28,778 & 27,098 \\
\hline B-16 & 175,787 & 136,976 & 169,162 & 204,130 & 192,880 & 22,564 & 19,311 & 20,647 & 25,611 & 24,688 \\
\hline B-17 & 299,387 & 216,390 & 291,928 & 335,475 & 353,754 & 36,127 & 28,210 & 34,929 & 40,030 & 41,339 \\
\hline Kajang & 270,625 & 189,974 & 264,336 & 322,993 & 305,198 & 32,437 & 24,051 & 31,772 & 37,626 & 36,299 \\
\hline Sri Kembangan & 313,096 & 216,556 & 267,643 & 355,705 & 412,480 & 37,269 & 26,557 & 31,639 & 42,691 & 48,188 \\
\hline Thai Knight & 311,920 & 210,647 & 324,986 & 373,790 & 338,256 & 34,784 & 24,786 & 35,149 & 40,332 & 38,869 \\
\hline LSD $(0.05)^{y}$ & 20,475 & 47,023 & 57,942 & 76,120 & 93,606 & 2570 & 6442 & 7275 & 9339 & 12,120 \\
\hline
\end{tabular}

${ }^{\mathrm{z}} 1$ fruit $/ \mathrm{ha}=0.4047$ fruit $/$ acre; $1 \mathrm{~kg} \cdot \mathrm{ha}^{-1}=0.8922 \mathrm{lb} /$ acre.

yeast significant difference at $P=0.05$

Data are the average of three locations.

than at other locations whereas average soluble solids concentration was significantly higher at Juana Diaz (Table 3 ).

At all locations, total number of fruit was significantly higher in 'Arkin' and 'Thai Knight' than in other cultivars and significantly lower in 'Kari' (Table 3). The number of marketable fruit produced by each cultivar varied among locations. At Corozal, there were no significant differences in marketable fruit production among top-producing cultivars B-17, Thai Knight, and Kari, which averaged 308,582 fruit/ha. 'Kajang' and 'B-17' were the highest producers of marketable fruit at Juana Diaz, averaging 320,392 fruit/ha. The number of marketable fruit produced by each cultivar at Isabela was not significantly different (Table 3 ). 'B-16' produced the lowest number of marketable fruit at all locations, but differences between 'B-16' and 'Lara' at Corozal and 'Arkin' and 'B-10' at Juana Diaz were not statistically significant (Table 3 ). As a percentage of total fruit production, 'Arkin' produced a significantly higher percentage $(75 \%)$ of nonmarketable fruit at all locations (data not shown) than other cultivars. This cultivar normally produced a large number of fruit, which may result in high sink demand for assimilates and smaller fruit.

Significantly higher yield of marketable fruit was obtained by 'Kajang', 'B-17', and 'Sri Kembangan' at Juana Diaz and 'B-17' at Corozal. 'Lara', 'B-16', and 'Kajang' produced significantly lower weight of marketable fruit per hectare than others at Corozal, whereas 'Arkin' and 'B-16' did so at Juana Diaz.
Weight of marketable fruit at Isabela was not significantly different among cultivars.

Individual weight of marketable fruit averaged over locations and cultivars was $120.2 \mathrm{~g}$ (data not shown). However, there was considerable deviation from this weight. At all locations individual weight of marketable fruit was significantly higher in 'B-10' and 'B-16', averaging $132.3 \mathrm{~g}$, whereas 'Kari' and 'Thai Knight' produced marketable fruit that weighed only an average of $111 \mathrm{~g}$ (data not shown).

'Kari' produced significantly longer fruit than other cultivars at all locations, whereas 'B-16' produced the shortest fruit overall (Table 3 ). 'B-10' and 'Lara' produced fruit with significantly greater fruit diameter than other cultivars at all locations, whereas those of 'Kari' and 'Sri Kembangan' produced fruit with the smallest diameter (Table 3). The highest soluble solids concentration values were obtained from fruit of 'B-17' at all locations, whereas the lowest values were obtained from 'Arkin' fruit.

In this study nine carambola cultivars were evaluated for the first time at three locations during 4 years of production. Overall, cultivars were highly adaptable to the diverse agroenvironments in which they were planted, although significantly higher yields of marketable fruit were obtained at Isabela (Oxisol) and Juana Diaz (Mollisol). The fact that 'B-17' had a high production of marketable fruit, high marketable yield, and significantly higher soluble solids concentration values than the rest of the cultivars at all locations makes this cultivar suitable for planting on various agroenvironments.

\section{Literature cited}

Campbell, C.W. 1997. Carambola cultivars in Florida. Proc. Fla. State Hort. Soc. 110:145-149.

Crane, J.H. 2005. Carambola growing in the Florida home landscape. Fact sheet HS 12, rev Horticultural Sciences Department, Florida Cooperative Extension Service, Institute of Food and Agricultural Sciences, University of Florida, Gainesville, FL.

Davis, K., E. Stover, and F. Wirth. 2004. Economics of fruit thinning: A review focusing on apple and citrus. HortTechnology 14:282-289.

Galan-Sauco, V., U.G. Menini, and H.D. Tindall. 1993. Carambola cultivation. FAO Plant Production and Protection paper no. 108. Food and Agriculture Organization of the United Nations, Rome.

Marler, T.E., A.P. George, R.J. Missen, and P.C. Andersen. 1994. Miscellaneous tropical fruits, p. 206-211. In: B. Schaffer and P.C. Andersen (eds.). Handbook of environmental physiology of fruit crops: II. Subtropical and tropical crops. CRC Press, Boca Raton, FL.

Mossler, M.A. and J.N. Nesheim. 2002. Florida crop/pest management profile: Carambola. 9 Aug. 2006. <http://edis. ifas.ufl.edu/PI056>.

Nakasone, H.Y. and R.E. Paull. 1998. Tropical fruits. CAB International, New York.

Shaw, P.E. and C.W. Wilson. 1998. Carambola and bilimbi, p. 521-556. In: P.E. Shaw, H.T. Chan, and S. Nagy (eds.). Tropical and subtropical fruits. Agscience, Auburndale, FL. 